\title{
TINJAUAN ELIPSIS PADA KALIMAT KONDISIONAL BAHASA ARAB
}

\author{
Afnan Arummi \\ afnanarummy85@gmail.com \\ Jurusan Sastra Arab \\ Fakultas Sastra dan Seni Rupa \\ Universitas Sebelas Maret \\ Pusat Studi Ekonomi Islam LPPM UNS
}

\begin{abstract}
One of the unique Arabic languages is an ellipsis system or one of the elements contained in an utterance. Among the Arabic sentence systems getting ellipsis is conditional sentences (al-jumlah a'sy-syarthiyyah). This article describes the study of ellipsis in Arabic conditional sentence reviewed from the linguistics perspective. The discussion in this study is focused on the theoretical concept of conditional sentences in Arabic and the concept of ellipsis (hadzf) specifically. Syntactic approach is used in this research to assess the grammatical structure as conditional markers, the relationship between the clauses of conditional sentences, the relationship between conditional sentences with other linguistic elements.
\end{abstract}

Keywords: ellipsis, Arabic conditional marker, protasis and apodosis

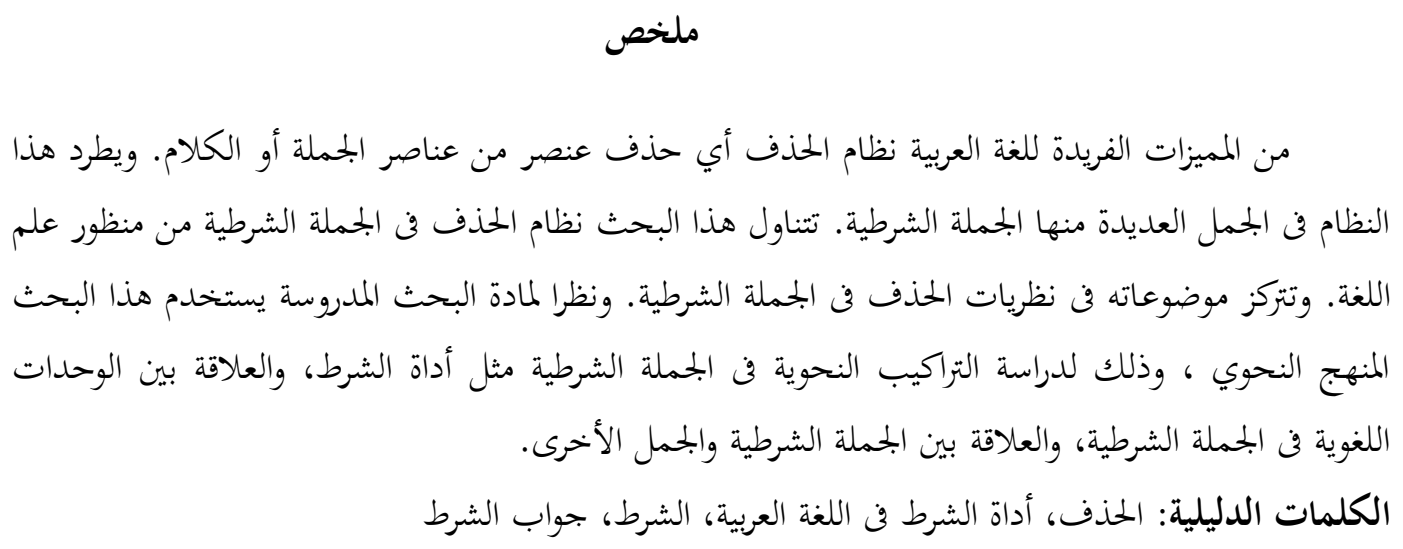

\section{A. Pendahuluan}

Sistem sintaksis sangat berkaitan erat dengan sifat keunikan dan keuniversalan bahasa. Dikatakan unik karena setiap bahasa mempunyai ciri khas sendiri yang tidak dimiliki oleh bahasa lainnya. Keunikan tersebut menyangkut sistem bunyi, sistem pembentukan kata, sistem pembentukan kalimat atau sistemsistem lainnya (Chaer, 2007: 51). Begitu pula dengan sifat keuniversalan bahasa, mengandung pengertian bahwa setiap bahasa memiliki satuan-satuan bahasa yang bermakna serta kesamaan sistem dalam hal konstruksi frasa, klausa, dan kalimat. Namun, proses terbentuknya satuan-satuan itu mungkin tidaklah sama (2007: 53).

Bahasa Arab yang bersifat inflektif (Chejne, 1994: 31) juga memiliki sistem tersebut, meskipun dalam penyebutan istilah-istilah seperti frasa, klausa, dan kalimat, tidak begitu populer di kalangan para pengkaji bA di Indonesia maupun di dunia Arab sendiri (Asrori, 2004: 31). Meskipun demikian bukan berarti dalam bA tidak ada konsep tentang ketiga obyek kajian sintaksis ini. Dalam buku-buku 
nahwu banyak dibahas berbagai konstruksi yang pada dasarnya merupakan konstruksi frasa, klausa, maupun kalimat seperti jarmajrūr, na'at man'üt, idhafah, murakab 'athfiy, murakab idhāfy, murakab bayāny, murakab isnādy, murakab ghairu isnādy, jumlah syarthiyyah, khabaru'l-jumlah dan lain-lain (2004: 32). Dilihat dari unsur pembentuknya, salah satu jenis yang terdapat pada sistem sintaksis Arab adalah al-jumlah a'sy-syartiyyah atau kalimat kondisional.

Dalam definisinya, kalimat kondisional merupakan suatu kalimat yang terdiri atas dua bagian. Bagian pertama merupakan syarat untuk berlaku atau tidaknya sesuatu, yang diterangkan dalam bagian kedua (Sokah, 1980: 70). Dalam kamus linguistik, susunan tersebut disebut juga dengan kalimat persyaratan yaitu kalimat bersusun yang mengandung protasis (klausa yang menyatakan syarat atau pengandaian dalam kalimat persyaratan) dan apodosis (klausa yang menyatakan akibat dalam kalimat persyaratan) (Kridalaksana, 2009:106).

Dilihat aspek gramatikanya, penulis berasumsi bahwa konstruksi kalimat kondisional atau persyaratan dalam bA tidak terbatas pada satu bentuk saja. Tentunya asumsi tersebut didasarkan pada fakta yang menyatakan bahwa bA memiliki kaedah terbanyak dibandingkan dengan bahasa-bahasa lain di dunia (Sokah, 1980: 82). Dengan demikian, halhal tersebut di atas mengindikasikan bahwa susunan kalimat kondisional dalam bA sangat beragam variannya. Salah satu varian yang terdapat dalam kalimat kondisional adalah elipsis ( $h a d z f)$.

\section{B. Pembahasan}

\section{Kalimat Kondisional dalam Linguistik Umum}

Penelitian ini berangkat dari sebuah teori sintaksis yang memiliki tiga bidang kajian yang meliputi tataran frasa, klausa, dan kalimat. Dalam bidang-bidang kajian ini didapati adanya hubungan-hubungan yang tidak hanya mencakup hubungan gramatika saja tetapi juga hubungan makna. Hubungan-hubungan makna ini timbul sebagai akibat pertemuan antar satuan bahasa tersebut dengan yang lainnya. Di antara hubungan-hubungan makna tersebut mencakup hubungan makna syarat (Ramlan, 1981:71). Hubungan syarat ini dapat diasumsikan sebagai satuan kondisional. Berlandaskan dengan teori yang yang dikemukakan oleh Ramlan, satuan ini dapat disepadankan dengan istilah al-jumlah a'sy-syarthiyyah, melihat kesamaan unsur yang terdapat di dalamnya.

\section{Pengertian al-jumlah a'sy- syarthiyyah. \\ Haywood \\ (1962:290)}

mendeskripsikan al-jumlah a'sysyarthiyyah sebagai kalimat bersyarat yang terdiri dari sebuah protasis (syarth), yaitu kalimat yang berisi persyaratan dan apodosis جَوَابُ الثَرَزْطِ (jawāb a'sy-syarthi), yang kalimat utamanya mengungkapkan apa yang akan ditimbulkan dari persyaratan tersebut. Dalam bA, protasis dan apodosis yang terletak dalam kalimat verbal memiliki kata kerja bentuk lampau atau verba perfek الفِعْلُ المأضِي (al-fi'lu'l$m \bar{a} d h \bar{\imath})$ atau verba imperfek الفِعْلُ الْمُضَارِعُ (al-fi'lu'l-mudhāri') tanpa makna temporal tertentu yang melekat.

Kridalaksana (2008: 130), mendefinisikannya dalam tiga klasifikasi bentuk pengertian yang saling berkaitan yaitu 1) kalimat persyaratan yaitu kalimat bersusun yang mengandung protasis ${ }^{1}$ dan apodosis $^{2}$. 2) klausa kondisional yaitu klausa yang menyatakan syarat atau

1 Protasis adalah klausa yang menyatakan syarat atau pengandaian dalam kalimat persyaratan; mis. bagian pertama dari kalau murah, barang itu akan saya beli (Kridalaksana 2008: 203).

2 Apodosis adalah klausa yang menyatakan akibat dalam kalimat persyaratan; mis. bagian kedua dari kalau murah, barang itu akan saya beli (2008: 18). 
pengandaian. 3) kondisional yaitu bentuk verba yang menunjukkan pengandaian atau hipotesis.

Tumijo dan Riyanto (2010: 55), mendefinisikan kalimat kondisional dengan kalimat pengandaian, yaitu kalimat yang digunakan untuk membuat pengandaian terhadap harapan, keinginan, rencana, dan lain-lain yang mungkin masih bisa terjadi, atau pengandaian yang bertentangan dengan fakta saat ini, ataupun pengandaian yang sudah tidak mungkin terjadi. Selanjutnya Al-Khuli mendefinisikannya sebagai klausa atau kalimat yang diawali dengan sebuah partikel yang menunjukan persyaratan yaitu " if" (Al-Khuli, 1982: 52).

Beberapa teori linguistik Arab berkenaan dengan kalimat kondisional juga dikemukakan oleh Ibrāhīm Ibrāhīm Barakāt (2007: 336). Ia menyebutnya sebagai a't-tarkīb a's-syarthī yaitu penggabungan dua klausa antara yang satu dengan lainnya dengan menggunakan penanda syarat yang memiliki keterikatan kala yang maknanya hanya dapat dipahami dengan menggabungkan secara lengkap unsur partikel, persyaratan, dan jawab syarat. Pendapat lain dikatakan bahwa kalimat kondisional disebut juga dengan al-jumlah al-mu'aqqadah yang terbentuk dari dua klausa; yang pertama disebut dengan syarat, dan yang kedua disebut dengan jawaban atau balasan, dan 'amil yang berfungsi mengaitkan keduanya yaitu penanda syarat (Nahr, 2008:1379).

Selain itu, Abd al-'Azīz (2003:309) mendefinisikan kalimat kondisional yaitu kalimat yang terbentuk dari dua susunan. Yang pertama merupakan susunan independen التَزَكْيْبُ المسنتَقِلُ (a't-tarkību'lmustaqī) yang disebut dengan klausa jawab atau jazā, dan yang kedua merupakan susunan dependen التَّزَكِيْبُ غَيْرْ المستَتِقِيْل (a't-tarkīb ghairu'l-mustaqìl) yang disebut klausa persyaratan. Kedua susunan tersebut dihubungkan dengan sebuah penanda kondisional, yang menjadikannya satu kalimat yang utuh.

Dari beberapa teori linguistik di atas, baik dari kalangan pengkaji linguistik umum maupun Arab yang berkenaan dengan definisi kalimat kondisional pada dasarnya sama. Setiap definisi menetapkan dua hal, (a) bahwa kalimat kondisional tersusun dari dua unsur; persyaratan dan jawaban syarat, (b) unsur pengikat hubungan makna antar kalimat yang satu dengan yang lain adalah penanda syarat.

Meskipun secara substansial sama, namun dari teori-teori tersebut penulis sependapat dengan rumusan teori yang dikemukakan oleh Abd al-'Azīz (2003:309) yang menyatakan bahwa kalimat kondisional merupakan gabungan dua susunan kalimat independen disebut dengan kalimat jawab, dan kalimat dependen disebut dengan kalimat persyaratan yang dihubungkan oleh adanya penanda syarat atau kondisional. Hal yang sama juga diungkapkan oleh Barakāt (2007) dan Nahr (2008).

\section{Penanda Kondisional Dalam Bahasa Arab}

Dibandingkan dengan penanda kondisional dalam bahasa lain, semisal bahasa Indonesia atau bahasa Inggris, kedudukan penanda kondisional dalam bA mempunyai pengaruh yang sangat besar dalam pembentukan kalimat kondisional, khususnya terhadap verba yang terletak di belakangnya (Sokah 1981: 72). Hal ini dikarenakan secara fungsi, penanda tersebut tidak hanya digunakan untuk menghubungkan antara satu klausa dengan klausa lainnya, melainkan juga berpengaruh pada perubahan akhir (deklinasi) harakāt setiap V yang terletak setelahnya, baik yang terdapat pada Protasis (klausa persyaratan) maupun pada Apodosis (klausa jawabnya).

Dalam bukunya, Abd Al-'Azīz (2003: 310) mengutip pendapat Ibnu Ya'īsy yang mengatakan bahwa masuknya sebuah penanda kondisional dalam sebuah kalimat berfungsi untuk menghubungkan 
antara klausa yang satu dengan lainnya, seperti pada kalimat إِنْ تُعْطِنِي أَشْكُرْكَ (in tu'thin̄ asykurka). Jika kalimat ini dikembalikan kepada bentuk $i$ 'rā $b^{3}$ asalnya tanpa didahului penanda kondisional adalah تُعْطِينِي أَشْكُرُكَكَ (tu'tīn̄ asykuruka). Pada awalnya antara kedua klausa tersebut

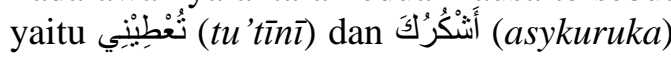
tidak mempunyai hubungan dalam hal keterkaitannya secara maknawi, namun ketika partikel إِن (in) yang merupakan penanda kondisional masuk, maka penanda ini menjadikan kedua klausa tersebut saling terikat dalam hubungan persyaratan serta menjadikan klausa yang pertama sebagai syarat dan kedua sebagai jawabannya.

Dalam bA, terdapat bermacammacam penanda kondisional. Jika ditinjau berdasarkan pengaruhnya terhadap verba, penanda kondisional menurut Barakāt (2007) dibagi menjadi tiga golongan yaitu: (1) Penanda kondisional apokopatif (yang menjazamkan) terdiri dari dua partikel: (in) dan إِذَّمَا (idzmā), serta sembilan nomina yaitu: مَ (man), مَنْ (matā), أَيَّانَ (ayyāna), أَنَىى (aina) (anna),

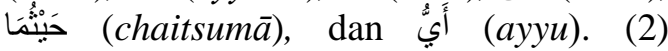
Penanda kondisional non-apokopatif (tidak menjazamkan) terdiri dari satu nomina: إِذَا $(i d z \bar{a})$, dan tiga partikel yaitu لَّ (lau), لَّلَ لَوْمَا (lau lau $m \bar{a})$ ), (3) Penanda

\footnotetext{
Kridalaksana

mendefinisikan i'rāb sebagai sebuah infleksi dengan desinens. Adapun desinens merupakan afiks penanda fleksi; misal dalam kata Latin dominus bentuk domin adalah akarnya, $u$ adalah vokal tematis dan $s$ adalah desinens. Dalam bA, i'rāb didefinisikan sebagai sebuah perubahan akhir atau syakal kata atau kalimah karena perbedaan 'amil yang memasukinya, baik perubahan yang tampak jelas secara lafadz atau hanya perkiraan saja keberadaannya. Terdapat empat macam i'rāb yang digunakan dalam bA, yaitu rafa' ditandai dengan dhammah, nashab ditandai dengan fatchah, rafadh atau jar ditandai dengan kasrah, dan jazam ditandai dengan sukūn (www.abatasa.com, diakses tanggal 2 mei 2011 pukul $19.30 \mathrm{WIB}$ ).
}

yang mengandung makna kondisional, terdiri dari dua nomina: كَيْقَ (kaifa) serta dua partikel أََّّ (ammā) dan لَ (lammā).

Dari pembagian di atas, dapat diketahui bahwa penanda kondisional dalam bA terdiri dari partikel dan nomina. Penanda-penanda ini mempunyai pengaruh terhadap perubahan atau i'rāb pada $\mathrm{V}$, khususnya verba imperfek (Vi). Perubahan yang terjadi pada $\mathrm{V}$ tersebut ditandai dengan jazam atau disukunkannya harakāt akhir pada $\mathrm{V}$ yang berkedudukan sebagai syarat atau protasis dan jawab atau apodosis, seperti pada contoh kalimat yang dikemukakan oleh Ibnu Ya'isy di atas. Penanda kondisional tidak dapat menjazamkan, jika V yang terletak setelahnya merupakan verba perfek (Vp). Hal ini dikarenakan verba tersebut termasuk dalam $\mathrm{V}$ indeclinable $(m a b n \bar{\imath})^{4}$ (V yang harakāt akhirnya tetap atau tidak mengalami perubahan).

Dalam hal yang berkaitan dengan fungsi jazam penanda kondisional di atas, Sokah (1980: 74) berpendapat bahwa yang sebenarnya menjazamkan V dalam Protasis dan Apod adalah partikel إنْ (in) yang dinyatakan secara implisit dalam penandapenanda kondisional, khususnya yang berasal dari N. Hal tersebut dapat dilihat secara jelas pada contoh kalimat berikut:

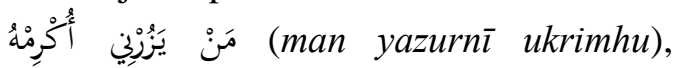

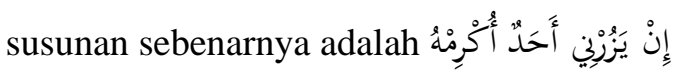
(in yazurn̄ achadun ukrimhu) 'jika seseorang mengunjungiku, aku akan memuliakannya'.

\section{Elipsis (Hadzf) dalam Susunan Kalimat Kondisional}

\section{a. Makna Elispsis}

Dalam sistem susunan kalimat kondisional, terdapat kaedah elipsis

${ }^{4}$ Indeclinable dalam tata bahasa berarti kata yang tak dapat berubah bentuknya. Dalam bA sering disebut dengan istilah mabnī atau mabniyyun. Istilah ini mengandung arti 'yang tetap dan tidak berubah' (Munawwir 1997: 112). 
(chadzf) yang berlaku pada salah satu komponen atau lebih dari susunan kalimat tersebut (Barakāt, 2007: 487). Secara bahasa, hadzf berarti memotong (qatha'a) dan menggugurkan (asqatha) (Ma'luf: 2008: 123). Jika kata tersebut dinisbahkan pada kalimat kondisional bA, maka elipsis (hadzf) dalam konteks tersebut dapat didefinisikan menjadi peniadaan atau pelesapan salah satu konstituen dalam susunan kalimat kondisional yang meliputi unsur penanda, unsur protasis (klausa syarat), dan unsur apodosis (klausa jawab). Beberapa contoh elispsis (hadzf) pada kalimat kondisional bA akan diuraikan sebagai berikut:

\section{b. Elipsis Verba Kondisional}

Dalam susunan kalimat
kondisional, sebuaha verba kondisional dapat dilesapkan. Hal ini dapat dilihat dari dua contoh susunan kalimat berikut:

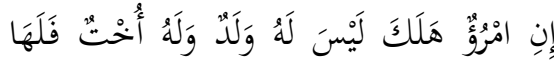

$$
\begin{aligned}
& \text { نِصْفُ مَا تَرَكَ }
\end{aligned}
$$

ini-m-ru'un halaka laisa lahū waladun wa lahū ukhtun falahā nishfu mā taraka

(in: pend kond + imru'un: indef $\mathrm{n}$. nom + halaka: vp. pron pers 3 tung $1 \mathrm{k} \ldots .$.

'Jika seorang meninggal dunia, dan ia tidak mempunyai anak dan mempunyai saudara perempuan, maka bagi saudaranya yang perempuan itu seperdua dari harta yang ditinggalkannya' (QS 4: 176).

Dalam susunan yang digarisbawahi, terdapat V kondisional yang dilesapkan. V tersebut merupakan $\mathrm{V}$ yang diinterpretasikan oleh $\mathrm{V}$ yang tampak setelahnya. Asumsi kalimat tersebut

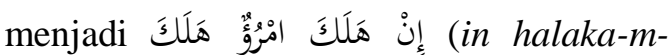
ru'un halaka). disebutkan:

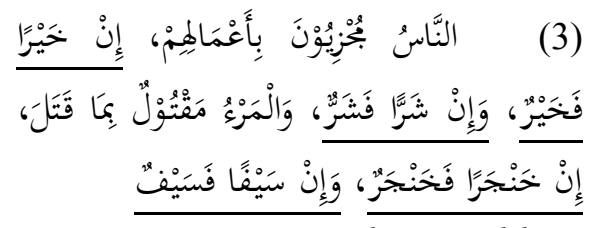

a'n-nāsu mujiziyūna bi a'mālihim, in khairan fa khairun, wa in syarran fa syarrun, wa'l-mar'u maqtūlun bimā qatala, in khinjaran $f a$ khinjarun, wa in saifan fa saifun

(... in: pend kond + khairan: khabar kāna $+f a$ : part attract + khairun: adj. nom ...)

'Manusia itu dibalas dengan apa yang mereka perbuat, jika baik maka (balasannya) baik, jika buruk maka (balasannya) juga buruk, dan seseorang itu dibunuh dengan apa yang ia bunuh, jika dengan belati maka (ia dibunuh dengan) belati, dan jika dengan pedang maka (juga dibunuh dengan) pedang' (NA: 468).

Dalam semua susunan yang digarisbawahi, terdapat $\mathrm{V}$ kondisional yang disembunyikan dan susunan sebenarnya dapat diasumsikan menjadi إنْ

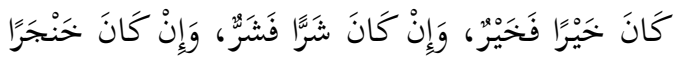

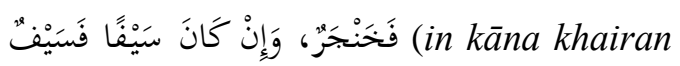
fa khairun, wa in kāna syarran fa syarrun, wa in kāna khinjaran fa khinjarun, wa in kāna saifan fa saifun).

\section{c. Elipsis Protasis}

Protasis dapat dilesapkan jika terletak setelah partikel (lillā) yang merupakan gabungan dari penanda kondisional apokopatif إِ (in) dan partikel negasi $\bar{\gamma}(l \bar{a})$.

Dalam susunannya, gabungan kedua partikel ini didahului oleh partikel konjungtif ' $(w a)$ sebagai penghubung dengan klausa sebelumnya yang terdiri dari jumlah a't-thalabiyyah (Barakāt, 2007: 469). Bentuk dan pola susunan kalimat ini dapat digambarkan sebagai berikut: 
Contoh:

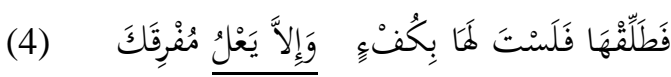
الخُحسَامُ

fathalliqhā falasta lahā bikuf' in, wa illā ya'lu mufriqaka al-chusāmu

(wa: part attract + illa : pend kond. part neg $+\boldsymbol{y} \boldsymbol{a}^{\prime} \mathbf{l u}$ : vi. pron pers 3 tung lk. nom. apod...)

'Maka tinggalkanlah ia karena anda tidak sebanding dengannya, dan jika tidak, pedangnya yang tajam akan membinasakanmu'. (NA: 469)

Protasis pada kalimat di atas dilesapkan atau disembunyikan. Dan asumsi dari susunan Protasis yang dilesapkan menjadi إِنْ لاَ تُطَلِقْهَها يَعْلُ (in lā tuthliqhā ya'lu).

Berkenaan dengan hal ini, Nahr (2007: 1395) dengan menggunakan istilah iqtishār (pemendekan klausa), berpendapat bahwa sebuah Protasis dapat dilesapkan atau disembunyikan jika penanda kondisional yang digunakan adalah إِ (in)

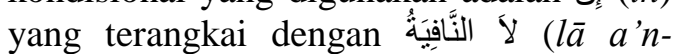
näfiyah). Selanjutnya ia mencontohkan dalam susunan kalimat yang lebih sederhana sebagai berikut:

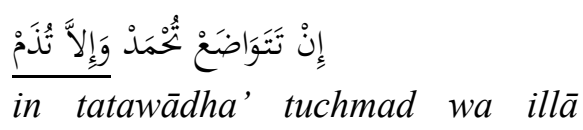
tudzam

(... wa: part attract + illa : pend kond. part neg + tudzam: vi. pass. pron pers 2 tung $\mathrm{lk}$. juss. apod)

'Jika anda rendah hati, maka anda akan dipuji, dan jika tidak anda akan dicela (dihinakan)'.

Bentuk asli dari susunan Protasis di

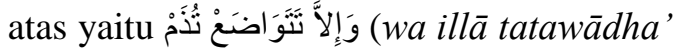
tudzam).

\section{d. Elipsis Penanda Kondisional dan Protasis}

Barakāt (2007: 470) menyebutkan bahwa elipsis penanda kondisional dan Protasis dapat disebut juga dengan istilah 'kalimat kondisional tanpa penanda'. Adapun Istilah yang digunakan dalam bA

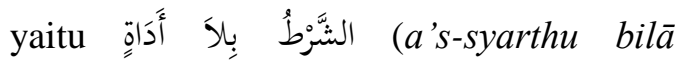
adātin $)^{5}$. Kedua komponen tersebut dapat dilesapkan atau disembunyikan jika terletak antara Apodosis yang sebelumnya didahului sebuah klausa atau kalimat lain. Contoh:

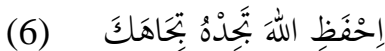

ichfadzi'l-lāha tajidhu tijāhaka

(ichfadzi: $\mathrm{v}$ imp. pron pers 2 tung $\mathrm{lk}$

+ a'l-läha: def n. ak. O + tajid: vi. pron pers 2 tung lk. juss. apod $+\boldsymbol{h u}$ : prom pers 3 tung $1 \mathrm{k}$. $\mathrm{O}+\boldsymbol{t}$ ija $\boldsymbol{h} \boldsymbol{h}$ : adv place. ak $+\boldsymbol{k} \boldsymbol{a}$ : prom pers 2 tung $\mathrm{lk}$ ) 'Jagalah (ingatlah) Allah, maka kamu akan mendapati-Nya Menjagamu'. (NA: 470)

إحْفَظِ اللهُ Asumsi kalimat ini adalah

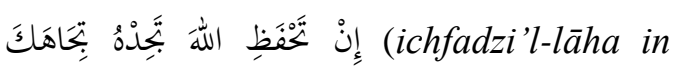
tachfidzi'l-lā̄ha tajidhu tijāhaka) 'jagalah (ingatlah) Allah, jika kamu menjaga (mengingat-Nya), maka kamu akan mendapati-Nya Menjagamu'. Dalam kalimat ini, penanda kondisional (in)

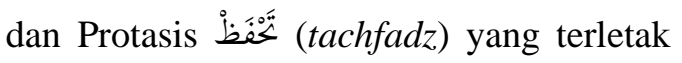
antara Apodosis بَتَحْدُ (tajidhu) dan jumlah a't-thalabiyyah إِحْفَظِ (ichfadzi'l-lāha) dilesapkan atau disembunyikan.

${ }^{5}$ Bentuk kalimat kondisional seperti ini, dapat disebut juga sebagai kalimat kondisional yang maknanya hanya dapat dapat dipahami dari sebuah konteks. Dalam susunannya, terkadang kalimat ini terdiri dari jumlah a'tthalabiyyah yang diikuti oleh klausa verbal yang terdiri dari jusif (Vi yang dijazamkan) (Abd Al-'Azīz, 2003: 313). Dari pendapat ini, dapat dinyatakan bahwa dalam beberapa kalimat kondisional, unsur Prot dan penanda kondisional dapat dilesapkan atau disembunyikan. 


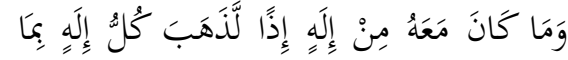
خَخَلَقَ

wa mā kāna ma'ahu min ilāhin idza-

l-ladzahaba kullu ilāhin bimā khalaqa

(... \{idza: part sanc $+\boldsymbol{l a}$ : part confir

+ dzahaba: vp. pron pers 3 tung $\mathrm{lk}$ ...\} apod)

'Dan sekali-kali tidak ada tuhan (yang lain) beserta-Nya, kalau ada tuhan beserta-Nya, masing-masing tuhan itu akan membawa makhluk yang diciptakannya (QS 23: 91).

Penanda kondisional dan Protasis yang dilesapkan dalam kalimat ini adalah

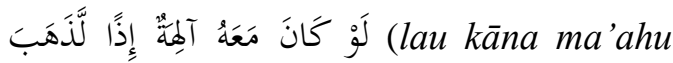
ālihatun idza-l-ladzahaba) yang diasumsikan terletak sebelum susunan

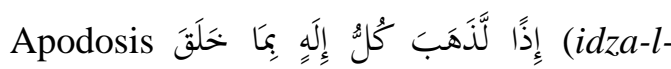
ladzahaba kullu ilāhin bimā khalaqa). Dengan demikian ayat tersebut selengkapnya dapat diartikan menjadi 'dan sekali-kali tidak ada tuhan (yang lain) beserta-Nya, kalau ada tuhan beserta-Nya, masing-masing tuhan itu akan membawa makhluk yang diciptakannya'.

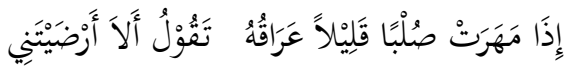

$\frac{\underline{\cos }}{i d z \bar{a} \bar{a}}$

'arāquhu, taqūlu alā ardhaitanī fataqarrabi

(...... $\{f a:$ part attract + taqarrabi: $\mathrm{v}$ imp. pron pers 2 tung $1 \mathrm{k}$ \} apod)

'ketika (seorang perempuan) menetapkan mahar yang sedikit, maka (ia) akan mengatakan: "hendaknya engkau ridha terhadapku, (jika engkau menginginkanku) maka mendekatlah kepadaku"

Dalam syair di atas, terdapat Protasis dan penanda kondisional yang dilesapkan dan terletak setelah jumlah a'tthalabiyyah yang mencakup makna

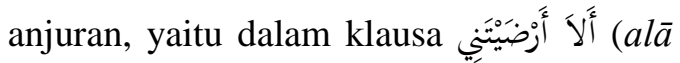

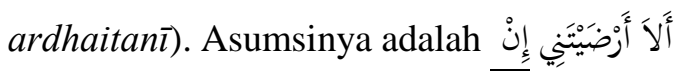

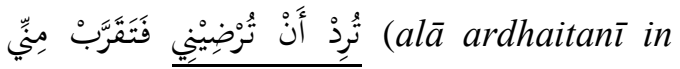
turid an turdhīn̄i fataqarrab minnī), dengan demikian syair tersebut dapat diartikan dengan 'ketika (seorang perempuan) menetapkan mahar yang sedikit, maka (ia) akan mengatakan: "hendaknya jika engkau menginginkanku maka mendekatlah kepadaku". Apodosis yang berlaku untuk Protasis tanpa penanda

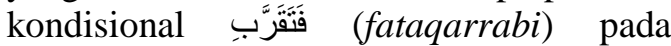
susunan kalimat di atas termasuk jumlah a't-thalabiyyah yang bermakna imperatif. Dalam bentuk ini, Apodosis tersebut wajib diawali dengan partikel فं $(f a)$.

\section{e. Elipsis Apodosis}

Selain Protasis dan penanda kondisional, elipsis juga berlaku pada Apodosis, baik dalam bentuk Vp maupun Vi. Dan dalam hal yang berkaitan dengan maknanya, Apodosis yang dilesapkan tersebut terinterpretasikan oleh $\mathrm{V}$ yang tampak (Barakāt, 2007: 470). Contoh:

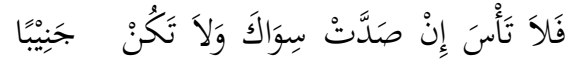

$$
\begin{aligned}
& \text { لحَلَالَّتِ كَذْوْبَ الْمَوَاعِدِ }
\end{aligned}
$$

Dalam kalimat ini, disebutkan adanya penanda kondisional yang diikuti Protasis إنْ صَدَّتَت (in shaddat). Sedangkan Apodosis yang seharusnya terletak setelah susunan tersebut, secara implisit maknanya telah disebutkan sebelumnya dalam klausa فَلاً تَأَسَ (falā ta'sa). Dengan demikian, makna Apodosis telah mendahului susunan penanda kondisional dan Protasis. Untuk 
itu, hal ini dianggap bahwa susunan Apodosis dilesapkan untuk menunjukkan apa yang telah mendahuluinya. Dan asumsi kalimatnya menjadi فِإنْ صَدَّتْ سِوَاكَ فَلاَ تَأْسَ (in shaddat falà ta'sa).

Elipsis Apodosis juga berlaku pada susunan kalimat yang lain. Seperti dalam contoh di bawah ini:

1) Apodosis yang terdiri dari susunan interogatif. Contoh:

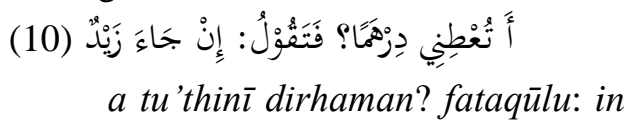
jā-a zaidun

(...... \{in: pend kond $+\boldsymbol{j} \bar{a}-\boldsymbol{a}$ :

vp. pron pers 3 tung $1 \mathrm{k}+$ zaidun: def n. nom. ag \} prot)

'Apakah anda akan memberi saya dirham? Maka anda jawab: jika Zaid datang'.

Asumsi kalimat tersebut menjadi إِنْ جَاءَ زَيْدُ أُعْطِكَ (in jâ-a zaidun u'thika)

'jika Zaid datang, saya akan memberimu (dirham)'. Klausa أُعْطِكَ (u'thika) merupakan Apodosis yang dilesapkan.

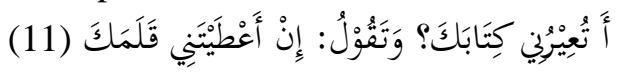

a tu' '̄runī kitābaka? Wa taqūlu. in a'thaitanī qalamaka

(...... \{in: pend kond $+\boldsymbol{a}$ 'thaita: vp. aff pers 2 tung $1 \mathrm{k}$. ag $+\boldsymbol{n} \overline{\boldsymbol{i}}$ : prom pers 1 tung $\mathrm{kk} / \mathrm{pr}$. $\mathrm{O}+$ qalama: indef n. ak. O. induk + $\boldsymbol{k} \boldsymbol{a}$ : prom pers 2 tung lk. modif prot)

'Apakah anda akan meminjami saya buku anda? Dan anda jawab: jika anda memberi saya pena milik anda'.

Asumsi kalimat tersebut adalah

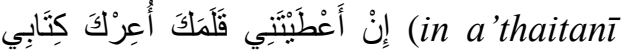
qalamaka u’irka kitāb $\overrightarrow{\text { ) }}$ 'jika anda memberi saya pena anda, saya akan meminjami anda buku saya'. Klausa أَعِرْكَكَ كِتَابِي (u'irka kitābī) merupakan Apodosis yang disembunyikan atau dilesapkan.
2) Susunan kalimat kondisional yang terdiri dari dua penanda kondisional dan dua protasis.

Jika terdapat susunan kalimat kondisional yang terdiri dari dua penanda kondisional dan dua Protasis yang tersusun secara berurutan, maka Apodosis-nya berlaku untuk salah satu dari dua susunan kalimat kondisional tersebut, sedangkan Apodosis lainnya dilesapakan. Akan tetapi, Apodosis yang tampak tersebut menginterpretasikan Apodosis yang dilesapkan. Contoh:

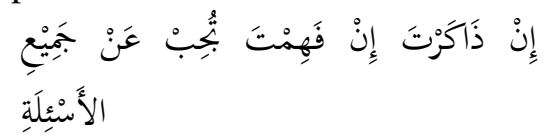

in dzākarta in fahimta tujib 'an jamī 'l-as'ilati

(in: pend kond + dzākarta: vp. aff pers 2 tung lk. prot + in: pend kond + fahimta: vp. aff pers 2 tung lk. prot + tujib: vi. pron pers 2 tung lk. juss. apod + 'an: prep + jamī: adv purp. gen. induk + al-as'ilati: def n. gen. modif)

'Jika anda hafal jika anda faham, maka anda akan dapat menjawab semua pertanyaan'.

Pada kalimat di atas, Apodosis (tujib 'an jamī alas'ilati) berlaku untuk salah satu Protasis saja. Adapun Apodosis dari Protasis yang lainnya dilesapkan, namun diinterpretasikan oleh Apodosis yang tampak tersebut.

3) Jika susunan juratif mendahului susunan kondisional, maka klausa jawab yang berada setelah kedua susunan tersebut berlaku untuk susunan juratif. Adapun klausa jawab yang berlaku untuk kalimat kondisional dilesapkan, namun diinterpretasikan oleh klausa jawab yang tampak atau yang berlaku untuk susunan juratif. Contoh:

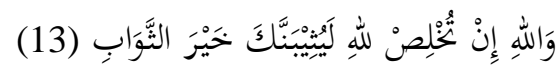


wa'l-lāhi in tukhlish li'l-lāhi layutsībannaka khairu'ts-tsawābi (wa'l-lāhi: part jur + in: pend kond + tukhlish: vi. pron pers 2 tung lk. juss. prot $+\boldsymbol{l i}$ : prep $+\boldsymbol{a} \boldsymbol{l}$ lāhi: def n. gen $+\{$ la: part confir + yutsība: vi. pron pers 3 tung lk. ak + na: part confir + $k a$ : prom pers 2 tung lk. O\} jawaban untuk part jur + khairu: adj. nom $+a$ 'tstsawābi: def n. gen)

'Demi Allah jika anda berbuat ikhlas karena Allah, maka Dia akan benar-benar akan membalas anda dengan sebaik-baik balasan'.

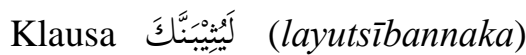

merupakan jawaban yang berlaku untuk susunan juratif. Adapun jawaban atau Apodosis untuk kalimat kondisional dilesapkan, namun terinterpretasikan oleh klausa jawab yang tampak tersebut.

\section{f. Elipsis Protasis dan Apodosis Secara Bersamaan}

Dalam kalimat tertentu, Protasis dan Apodosis yang terletak setelah penanda kondisional إِن (in) dapat dilesapkan secara bersamaan. Dengan kata lain, hanya penanda kondisional saja yang tampak. Bentuk elipsis seperti ini hanya berlaku di dalam syair dengan syarat susunan kalimat yang tampak memberi petunjuk tentang adanya makna susunan Protasis dan Apodosis yang disembunyikan Contoh:

$$
\begin{aligned}
& \text { قَالَتْ بَنَاتُ العَمِّ يَا سَلْمَى وَإِنْ عَانَ فَفَيْرًا } \\
& \text { مُعْدِمًا قَالَتْ وَرإِنْ }
\end{aligned}
$$

qālat banātu'l- 'ammi yā salmā wa in kāna faqūran mu'diman qālat wa in.

part attract $+\boldsymbol{i n}$ : pend kond)

wa:

Syair di atas, akan mudah dipahami dengan jelas jika diberi tanda baca sebagai berikut: قَالَتْ بَنَاتُ العَبِّ: يَا سَلْمَى، وَإِنْ كَانَ فَفَيْرًا
مُعْدِمًا؟ قَالَتْ: وَإِنْ (qālat banātu'l- 'ammi: yā salmā, wa in kāna faqīran mu'diman? Qālat: wa in). Dengan demikian, syair tersebut dapat diartikan menjadi 'anak perempuan paman berkata: wahai Salma, walaupun (dia) seorang yang miskin dan tidak berada? Dia (Salma) menjawab: walaupun'.

Di dalam syair ini terdapat susunan kalimat kondisional yang Protasis dan Apodosis-nya dilesapkan atau disembunyikan, namun terdapat petunjuk keberadaan kedua komponen kalimat kondisional yang dilesapkan tersebut dari konteks susunannya. Dan Protasis dan Apodosis tersebut dapat diasumsikan

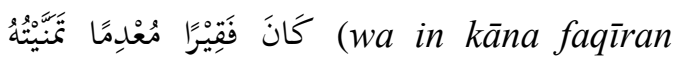
mu'diman tamannaituhu) 'walaupun dia seorang miskin dan tak berada, aku menginginkannya'.

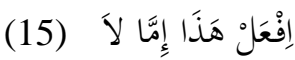

if'al hādza immā lā

(....... imm $\overline{\boldsymbol{a}}$ : pend kond $+\boldsymbol{l} \overline{\boldsymbol{a}}$ : part

neg) tidak'.

'Lakukkan (pekerjaan) ini atau

Dalam kalimat ini terdapat Protasis dan Apodosis yang dilesapkan atau disembunyikan secara bersamaan. Asumsi kalimat tersebut adalah إنْ كُنْتَ لَ تَفْعَنُ غَيْرَهُ فَافْعَلُُْ (in kunta là taf'alu ghairahu faf'alhu) 'jika anda tidak mengerjakan pekerjaan ini, maka kerjakan pekerjaan selainnya'.

\section{g. Elipsis Protasis Setelah Jumlah A't-Thalabiyyah}

Dalam beberapa susunan kalimat, penanda kondisional, khususnya partikel إن (in) dan Protasis dilesapkan jika terletak setelah jumlah a't-thalabiyyah. Contoh: hawā-u

iftachi'n-nāfidzata yatajaddad al-

(iftach: $\mathrm{v}$ imp. pron pers 2 tung $\mathrm{lk}+$ a'n-näfidzata: def n. ak. $\mathrm{O}+$ 
$\{$ yatajaddad: vi. pron pers 3 tung $1 \mathrm{k}$. juss. $\mathrm{P} / \mathrm{M}+\boldsymbol{a l}$-haw $\overline{\boldsymbol{a}}-\boldsymbol{u}$ : def n. nom. ag\} apod)

'Bukalah jendela itu, maka udara baru akan masuk'.

Asumsi dari kalimat di atas adalah

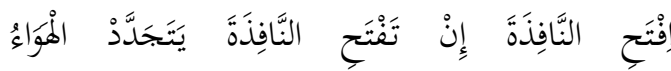
(iftachi'n-nāfidzata in taftachi'n-näfidzata yatajaddad al-hawā-u) 'bukalah jendela itu, jika anda membuka jendela itu maka udara baru akan masuk'. Klausa jawab dari jumlah a't-thalabiyyah yang mencakup makna imperatif يَتَجََْْن (yatajaddad) dijazamkan karena $\mathrm{V}$ tersebut merupakan Apodosis yang berlaku untuk penanda kondisional dan Protasis yang disembunyikan إنْ تَفْتَح النَّفَفَة (in taftachi'nnāfidzata).

Sebaliknya, jika jumlah $a^{\prime}$ tthalabiyyah terdiri dari kalimat pelarangan (prohibitif) maka jawaban harus mengandung makna yang dipandang baik (sesuatu yang disukai). Karena Protasis tersembunyi dalam kalimat prohibitif tersebut merupakan kalimat yang dinegatifkan.

Jika sebuah kalimat dinegatifkan, maka biasanya mengandung makna yang dipandang tidak baik (sesuatu yang tidak disukai). Oleh karena itu, jawabannya harus mengandung makna sesuatu yang dipandang baik. Misalnya: لَّ تَنَنْ مِنَ الأسََدَ

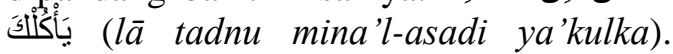
Dengan menginterpretasikan penanda kondisional dan Protasis yang dilesapkan,

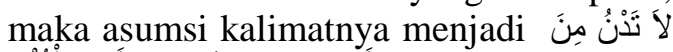

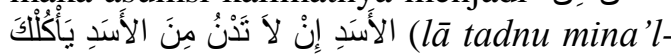
asadi in là tadnu mina 'l-asad ya'kulka)' jangan dekati singa, jika kamu tidak mendekati singa, maka ia akan memakanmu'. Kalimat ini dapat disama artikan dengan 'jauhilah singa, maka ia akan memakanmu'. Tentunya hal tersebut sangat tidak mungkin terjadi.

Jika diperhatikan, makna kalimat ini menjadi tidak jelas karena pemilihan $\mathrm{V}$ dalam klausa jawab yang tidak tepat. Dalam hal ini, susunan Apodosis yang tepat untuk jumlah a't-thalabiyyah yang mengandung makna prohibitif dapat diamati pada contoh berikut:

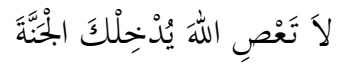

là ta'shi'l-lāha yudkhilka'l-jannata (lāa: part interdic + ta'shi: vi. pron pers 2 tung lk + a'l-läha: def $\mathrm{n}$. ak. $\mathrm{O}+$ \{yudkhil: vi. pron pers 3 tung lk. juss. $\mathrm{P} / \mathrm{M}+\boldsymbol{k a}$ : prom pers 2 tung lk. $\mathrm{O}+$ al-jannata: def n. ak. O apod)

janganlah kamu bermaksiat kepada Allah, (jika kamu tidak bermaksiat kepada Allah), maka Dia akan memasukkanmu ke dalam surga'.

Susunan yang sebenarnya dari

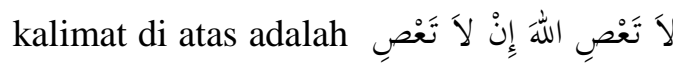
(lā ta'shi'l-lāha, in lā ta'shi'l-lāha yudkhilka'l-jannata). Dengan demikian kalimat tersebut dapat diartikan menjadi 'janganlah kamu bermaksiat kepada Allah, jika kamu tidak bermaksiat kepada Allah, maka Dia akan memasukkanmu ke dalam surga'.

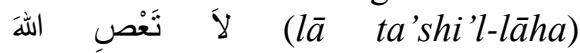

merupakan jumlah a't-thalabiyyah yang mengandung makna prohibitif

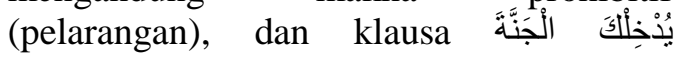
(yudkhilka'l-jannata) merupakan Apodosis-nya. Dalam bentuk kalimat seperti ini terdapat protasis yang disembunyikan yaitu إِنْ لَا تَنَص الهَ (in la ta'shi'l-lāha)

Dan berikut beberapa contoh penjazaman Apodosis yang berlaku untuk jumlah a't-thalabiyyah:

1) Penjazaman Apodosis untuk jumlah a't-thalabiyyah yang mencakup makna imperatif. Contoh:

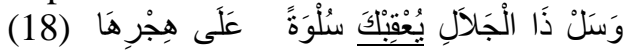

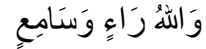 wasal dzā'l-jalāli yu'qibka sulwatan, 'alā hijrihā wa'l-lahu rā-in wa sāmi'in
(....... \{yu'qib: vi. pron pers 3 tung $\mathrm{lk}$. juss. $\mathrm{P} / \mathrm{M}+\boldsymbol{k} \boldsymbol{a}$ : prom pers 2 tung $1 \mathrm{k} . \mathrm{O}$ \} apod .....) 
'Dan mintalah kepada Yang Memiliki Keagungan, maka Dia akan memberimu kebahagiaan atas apa yang telah hilang, dan Allah Maha Melihat dan Mendengar.

Vi يُعْقِبْ (yu'qib) yang terletak setelah jumlah a't-thalabìyah dan mencakup makna imperatif سَّ (sal) dijazamkan. Vi tersebut dijazamkan, karena merupakan Apodosis untuk penanda kondisional dan Protasis yang terlesapkan. Dan asumsi kalimatnya menjadi إِنْ تَسَلْ ذَا الْجَلاَلِ يُعْقِبَْكَ (in tasal dzā'l-jalāli yu'qibka).

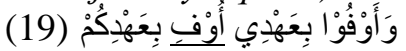

wa aufū bi 'ahdī ūfi bi 'ahdikum

(......... $\overline{\boldsymbol{u}} f \mathbf{i}$ : vi. pron pers 1 tung

lk. juss. P/M. apod ....)

'Dan penuhilah janjimu kepada-

$\mathrm{Ku}$, niscaya $\mathrm{Aku}$ penuhi janji-Ku kepadamu' (QS 2: 40).

Vi أُوْفِ (üfi) dijazamkan karena merupakan jawaban dari jumlah a'tthalabiyyah yang mencakup makna imperatif. Selain itu, V tersebut berlaku sebagai Apodosis untuk penanda kondisional dan Protasis yang dilesapkan. Adapun asumsi kalimatnya menjadi إنْ تُوْفُوْا أُوْفِ (in tūfū ūfi) 'jika kalian memenuhi (janji), akan Aku penuhi (janji-Ku)'.

2) Penjazaman Apodosis untuk jumlah a't-thalabiyyah yang mencakup makna interogatif. Contoh:

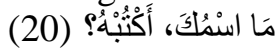

mā ismuka, aktubhu?

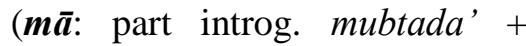
\{ismu: indef n. nom. induk $+\boldsymbol{k a}$ : prom pers 2 tung $1 \mathrm{k}$. modif khabar $+\{\boldsymbol{a k t u b}:$ vi. pron pers 1 tung lk. juss. $\mathrm{P} / \mathrm{M}+\boldsymbol{h} \boldsymbol{u}$ : prom pers 3 tung lk. sub. O \} apod? 'Siapa namamu, saya tuliskan?'

Vi أَكْتُبْ (aktub) pada kalimat interogatif di atas dijazamkan, karena merupakan Apodosis untuk penanda kondisional dan Protasis yang disembunyikan. Dan asumsi kalimatnya

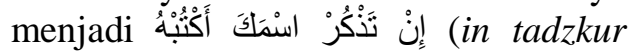
ismaka aktubhu) 'jika anda menyebutkan namamu saya tuliskan'.

3) Penjazaman Apodosis untuk jumlah a't-thalabiyyah yang mencakup makna pelarangan (prohobitif/interdiktif). Contoh:

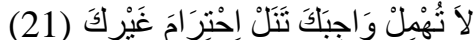
lā tuhmil wäjibaka tanal ichtirāma ghairika

(lā: part interdic + tuhmil: vi. pron pers 2 tung lk. juss. P/M + wājiba: indef n. ak. O. induk + $\boldsymbol{k a}$ : prom pers 2 tung lk. modif + \{tanal: vi. pron pers 2 tung $1 \mathrm{k}$. juss + ichtirāma: indef n. ak. $\mathrm{O}+$ ghairi: indef n. gen. induk $+\boldsymbol{k a}$ : prom pers 2 tung lk. sub. modif\} apod)

'jangan remehkan kewajiban anda, (jika anda tidak meremehkan kewajiban anda), maka anda akan mendapat penghargaan (penghormatan) dari orang lain'.

Pada kalimat ini, terdapat penanda kondisional dan Protasis yang dilesapkan. Dengan memunculkan kedua komponen kalimat kondisional tersebut, maka asumsi kalimatnya

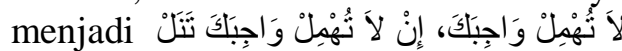
إحْتِرَاحَ غَيْركَ (lā tuhmil wājibaka, in lā tuhmil wājibaka tanal ichtirāma ghairika). Oleh karena itu, pemaknaannya kalimat tersebut menjadi 'jangan remehkan kewajiban anda, jika anda tidak meremehkan kewajiban anda, maka anda akan mendapat penghargaan (penghormatan) dari orang lain'.

Vi تَنَ (tanal) dijazamkan, karena berkedudukan sebagai Apodosis untuk Protasis yang disembunyikan. Adapun asumsi Protasis yang disembunyikan

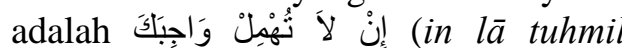
wājibaka). Kalimat ini merupakan kalimat penafikkan. 
4) Penjazaman Apodosis untuk jumlah a't-thalabiyyah yang mencakup makna $a^{\prime} r$-rajā atau pengharapan. Contoh:

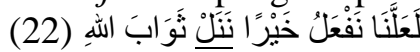

la'allanā naf'alu khairan, nanal tsawāba'l-lāhi

(la'alla: part solic $+\boldsymbol{n} \overline{\boldsymbol{a}}$ : prom pers 1 plur $1 \mathrm{k} / \mathrm{pr}+$ naf'alu: vi. pron pers 1 plur lk/pr. nom. ag + khairan: adj. ak $+\{$ nanal: vi. pron pers 1 plur $\mathrm{lk} / \mathrm{pr}$. juss + tsawäba: indef n. ak. induk + a'llähi: def n. gen. modif\} apod)

'Semoga kami dapat mengerjakan kebaikan, maka kami akan mendapat pahala dari Allah'.

Vi iَنَ (nanal) dijazamkan karena merupakan Apodosis dari penanda kondisional dan Protasis yang disembunyikan. Dengan menampakkan Protasis yang disembunyikan, maka

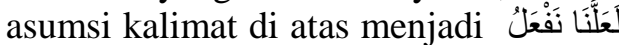
خَيْرًا إنْ نَفْعَلْ خَيْرًا نَتَلْ تَوَابَ اللهِ (la'allanā naf'alu khairan, in naf'al khairan nanal tsawāba'l-lāhi).

5) Penjazaman Apodosis untuk jumlah a't-thalabiyyah yang mencakup makna al-muna $\bar{a}$ (keinginan dan cita-cita). Contoh:

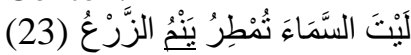
laita's-samā-a tumthiru yanmu'zzar'u

(laita: part wish + a's-samā-a: def n. ak. mubtada'. ism laita + tumthiru: vi. pron pers 3 tung pr. nom. P/M. khabar laita + \{yanmu: vi. pron pers 3 tung $1 \mathrm{k}$. juss + $\boldsymbol{a}^{\prime} \boldsymbol{z}$-zar'u: def n. nom. ag apod)

'Sekiranya langit menurunkan air hujan, maka tanaman akan tumbuh'.

Vi يَنْ (yanmu) dijazamkan, karena merupakan jawaban atau Apodosis dari penanda kondisional dan Protasis yang disembunyikan. Kalimat tersebut dapat diasumsikan dengan

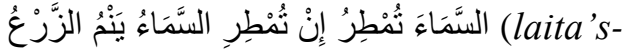
samā-a tumthiru, in tumthiri's-samā'u yanmu'z-zar'u). Adapun tanda jazam Vi pada Apodosis tersebut adalah dilesapkannya partikel defektif atau charf 'illah , (wau), karena asalnya

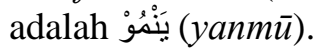

6) Penjazaman Apodosis untuk jumlah a't-thalabiyyah yang mencakup makna anjuran. Contoh:

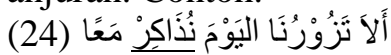
alā tazūrunā'l-yauma nudzākir ma'an

(alä: part excit + tazūru: vi. pron pers 2 tung lk. nom. $\mathrm{P} / \mathrm{M}+\boldsymbol{n} \overline{\boldsymbol{a}}$ : prom pers 1 plur $1 \mathrm{k} / \mathrm{pr}+\boldsymbol{a l}$ yauma: adv time. ak + \{nudzäkir: vi. pron pers 1 plur lk/pr. juss + ma'an: adv. chāl\} apod)

'Hendaknya anda mengunjungi kami hari ini, maka kita akan belajar bersama'.

Vi نُذَاكِرْ (nudzākir) merupakan jawaban atau Apodosis dari penanda kondisional dan Protasis tersembunyi, untuk itu dijazamkan. Asumsinya

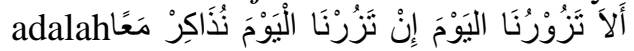
(alā tazūrunā'l-yauma in tazūrnā'lyauma nudzākir ma'an).

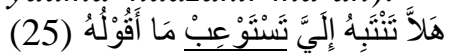

hallā tantabihu ilayya tastau'ib $m \bar{a}$ aqūluhu

(hallā: part excit + tantabihu: vi. pron pers 2 tung lk. nom. P/M + $\boldsymbol{i} \boldsymbol{l a}$ : prep $+\boldsymbol{y} \boldsymbol{a}$ : prom pers 1 tung $1 \mathrm{k} / \mathrm{pr}+\{$ tastau'ib: vi. pron pers 2 tung lk. juss $+\boldsymbol{m} \overline{\boldsymbol{a}}$ : conj $\mathrm{n}+$ aqūlu: vi. pron pers 1 tung $1 \mathrm{k} / \mathrm{pr}$ $+\boldsymbol{h u}$ : prom pers 3 tung lk. sub\} apod)

mengapa anda tidak memperhatikan saya, (jika anda memperhatikan saya), anda akan memahami apa yang saya katakan'

Dengan menginterpretasikan penanda kondisional dan Protasis yang 
tersembunyi, asumsi kalimat ini

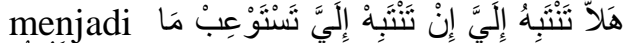
أَفُوْلُدُ (halla tantabihu ilayya, in tantabih ilayya tastau'ib mā aqūluhu). Dengan demikian, selengkapnya pemaknaan kalimat di atas menjadi 'mengapa anda tidak memperhatikan saya, jika anda memperhatikan saya, anda akan memahami apa yang saya katakan'. Dan seperti yang tampak pada kalimat ini, bahwa Vi تَسْنَوْعِبْ (tastau'ib) dijazamkan, karena merupakan Apodosis dari Protasis yang disembunyikan.

7) Penjazaman Apodosis untuk jumlah a't-thalabiyyah yang mencakup makna a'n-nida atau vokatif. Contoh:

يَا مَحْمُوْدُ أَفْبْلْ تَنَلْنَ مَقْعَدًا (26)

yā machmūd aqbil tanal maq'adan

$(y \bar{a}:$ part voc + machmū $\overline{d u}: \operatorname{def}$ n. nom + aqbil: $\mathrm{v}$ imp. pron pers 2 tung lk. juss $+\{$ tanal: vi. pron pers 2 tung $\mathrm{lk}$. juss. $\mathrm{P} / \mathrm{M}+$ maq'adan: def n. ak. O\} apod)

'Wahai Mahmud terimalah, maka kamu akan mendapatkan tempat duduk (bangku).

Vi نَّin (tanal) merupakan jawaban atau Apodosis untuk penanda kondisional dan Protasis yang disembunyikan, untuk itu dapat dijazamkan. Asumsi kalimatnya

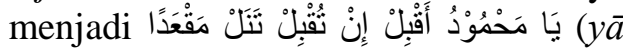
machmūd aqbil, in tuqbil tanal maq'adan).

8) Penjazaman Apodosis untuk nomina verbal (ism fi'l). Contoh:

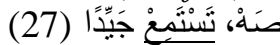

shah, tastami' jayyidan

(shah: $\mathrm{v} \mathrm{n}+$ \{tastami': vi. pron pers 2 tung lk. juss + jayyidan: adv. $\operatorname{ch} \bar{a} l)$

'diamlah! (jika anda diam), maka anda akan dapat mendengar dengan baik'

Dengan menginterpretasikan penanda kondisional dan Protasis yang
صنَهُ إِنْ

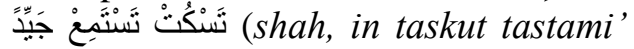
jayyidan). Maka kalimat di atas dapat diartikan secara lengkap menjadi, 'diamlah! Jika anda diam, maka anda akan dapat mendengar dengan baik'. Adapun Vi نَسْنَّنَ (tastami') dijazamkan, karena merupakan Apodosis dari Protasis yang disembunyikan Demikian pula dengan contoh-contoh kalimat berikut ini:

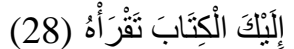

ilaika'l-kitāba taqra'hu

(ilaika: v n + al-kitāba: def n. ak. $\mathrm{O}+$ \{taqra': vi. pron pers 2 tung lk. juss $+\boldsymbol{h} \boldsymbol{u}$ : prom pers 3 tung lk. sub\} apod)

'terimalah buku ini, (jika anda menerima buku ini), maka anda akan membacanya'

Makna yang terdapat dalam tanda kurung merupakan asumsi dari susunan penanda kondisional dan Protasis yang dilesapkan. Karena susunan sebenarnya adalah إِلَّْكَ الْكِنَابَ إِنَ (ilaika'l-kitāba in tuqbili'l-kitāba taqra'hu). Untuk itu pemaknaan kalimat di atas menjadi 'terimalah buku ini, jika anda menerima buku ini, maka anda akan membacanya'. 'تَقْرَ (taqra') merupakan jusif untuk penanda kondisional dan Protasis yang disembunyikan.

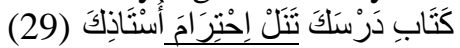
katābi darsaka tanal ichtirāma ustādzika

(katābi: v n + darsa: indef n. ak. O. induk $+\boldsymbol{k} \boldsymbol{a}$ : prom pers 2 tung lk. modif + tanal: vi. pron pers 2 tung $1 \mathrm{k}$. juss + ichtirāma: adv caus K3/ maf'ul li-ajlih + ustādzi: indef n. gen $+\boldsymbol{k a}$ : prom pers 2 tung lk. sub)

'tulislah pelajaranmu, (jika kamu menulisnya,) maka kamu akan mendapat penghargaan gurumu'

Dengan menginterpretasikan penanda kondisional dan Protasis yang dilesapkan, asumsi susunan kalimat di 


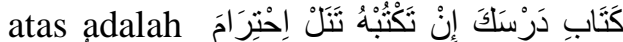
أَسْتَاذِكَكَ (katābi darsaka, in taktubhu tanal ichtirāma ustādzika). Oleh karena itu, kalimat tersebut dapat di artikan menjadi 'tulislah pelajaranmu, jika kamu menulisnya, maka kamu akan mendapat penghargaan gurumu'. Vi نَنَ (tanal) dijazamkan oleh penanda kondisional dan Protasis yang tersembunyi.

9) Penjazaman Apodosis untuk jumlah a't-thalabiyyah yang mengandung makna do'a. Contoh:

$$
\begin{aligned}
& \text { غَفَرَ اللهُ لِزَيَدِ يُخْخِلْهُ الْجَنََّة (30) } \\
& \text { ghafarallāhu }
\end{aligned}
$$

lizaidin

yudkhilhu'l-jannata

(ghafara: vp. pron pers 3 tung lk

$+\boldsymbol{a} \boldsymbol{l}$-lähu: def n. nom + li: prep

+ zaidin: def $\mathrm{n}$. gen $+\{$ yudkhil:

vi. pron pers 3 tung lk. juss $+\boldsymbol{h u}$ : prom pers 3 tung lk. sub $+a l$ jannata: indef n. ak. O apod) '(jika) Dia mengampuni Zaid, maka Dia akan memasukkannya ke dalam surga'

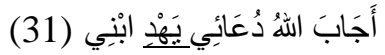
ajāballāhu du' $\bar{a}-\bar{\imath}$ yahdi-bnī (ajāba: vp. pron pers 3 tung $1 \mathrm{k}+$ a'l-lāhu: def n. nom. ag + du' $\overline{\boldsymbol{a}}-\overline{\boldsymbol{\imath}}$ : indef $\mathrm{n}$. prom pers 1 tung lk/pr + \{yahdi: vi. pron pers 3 tung $1 \mathrm{k}$. juss $+\boldsymbol{i} \boldsymbol{b} \boldsymbol{n} \overline{\boldsymbol{i}}$ : indef $\mathrm{n}$. prom pers 1 tung $1 \mathrm{k} / \mathrm{pr}$ \} apod)

(jika) Dia mengabulkan do'aku, maka Dia akan memberikan hidayah-Nya pada anakku'

Asumsi kalimat (30) adalah يَغْفِرْ لزَزَيٍْ يُخْخِلْهُ الْجَنَّةَ (in yaghfir lizaidin yudkhilhu'l-jannata)

'jika Dia mengampuni Zaid, maka Dia akan memasukkannya ke dalam surga'.

Adapun asumsi kalimat (31)

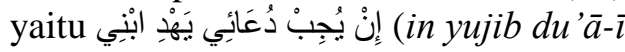
yahdi-bn $\bar{\imath}$ ) 'jika Dia mengabulkan do'aku, maka Dia akan memberikan hidayah-Nya pada anakku'. Kedua Vi dalam dua susunan kalimat di atas يُنْخِل (yudkhil) dan يَ يَزْ (yahdi) dijazamkan, karena merupakan Apodosis untuk Protasis tersembunyi setelah jumlah a't-thalabiyyah yang mengandung makna do'a.

\section{Kesimpulan}

Elipsis ( $h a d z f)$ dalam semua sistem kebahasaan pada dasarnya memiliki pengertian yang sama, yaitu peniadaan atau pelesapan salah satu unsur yang terdapat pada suatu ujaran. Dalam proses pelesapan tersebut tentu saja dibarengi dengan adanya unsur lain yang menunjukkan unsur atau komponen kalimat yang mengalami elipsis (hadzf). Beberapa unsur dalam kalimat kondisional bahasa Arab yang dapat dilesapkan meliputi unsur penanda, unsur protasis, dan unsur apodosis. Dengan demikian, konsep elipsis dalam sistem kalimat ini memiliki beberapa kemungkinan, di antaranya; pelesapan unsur verba kondisional, pelesapan protasis, pelesapan penanda kondisional dan protasis, pelesapan apodosis, pelesapan protasis dan apodosis secara bersamaan, serta pelesapan protasis setelah Jumlah A't-Thalabiyyah yang mencakup makna imperative, makna interogatif, makna pelarangan (prohobitif/interdiktif), makna a'r-rajā atau pengharapan, makna al-munā (citacita), makna anjuran, makna a'n-nidā (vokatif), nomina verbal (ism $f i^{\prime} l$ ), dan yang mencakup makna do'a.

\section{Daftar Pustaka}

Al-Qur'ān Digital Versi 2.0. 2004 M/ 1425 H. Website http://www.alqurandigital.com

Asrori, Imam. 2004. Sintaksis BA, Frasa, Klausa, dan Kalimat. Cetakan Pertama. Malang: Penerbit Misykat. 
Al-'Azīz, Muhammad Hasan Abd. 2003. A'r-Rabthu Baina'l-Jumal fi'llughat Al-'Arabiyyah AlMu'āshirah. Cetakan pertama. Kairo: Dār Al-Fikr Al-`Arabiy.

Al-Khulli, Muhammad Ali. 1982. A Dictionary of Theoretical Linguistics, English-Arabic. Cetakan Pertama. Beirut: Libraire Du Luban.

Barakāt, Ibrāhīm Ibrāhīm. 2007. A'nNahwu Al-'Araby. Juz kelima. Cetakan pertama. Kairo: Dār A'nNasyr Li Al-Jāmi'ah.

Chaer, Abdul. 2007. Kajian Bahasa: Struktur Internal, Pemakaian, dan Pemelajaran. Jakarta: PT. Rineka Cipta.

Chejne, Anwar G. 1994. BA dan Peranannya Dalam Sejarah. Terj. Aliudin Mahjudin. Jakarta: Pusat Pembinaan dan Pengembangan Bahasa.

Haywood, J. A., Nahmad, H. M. 1962. A New Arabic Grammar of The Written Language. Edisi keenam. Great Britain: Percy Lund, Humpries and Co. Ltd.
Kridalaksana, Harimurti. 2009. Kamus Linguistik. Edisi Keempat. Jakarta: PT Gramedia Pustaka Utama.

Munawwir, Ahmad Warson. 1997. AlMunawwir, Kamus ArabIndonesia. Cetakan keempatbelas. Surabaya: Penerbit Pustaka Progressif.

Ma'lūf, Louis. 2008. Al-Munjid: Fi'llughati Wa'l-A'làm. Cetakan keempat puluh tiga. Beirut: Dār Al-Masyriq.

Nahr, Hādī. 2008. A'n-nahwu A't-tathbiqī. Cetakan kedua, Yordania: 'Ālamu Al-Kutub Wa Al-Chadīts Press.

Ramlan. M. 2005. Tata Bahasa Indonesia, Sintaksis. Cetakan kesembilan. Yogyakarta: C. V. Kardoyo.

Sokah, Umar Asasuddin. 1980. Kalimat Kondisional Bahasa Inggris, Arab, dan Indonesia (Suatu Studi Perbandingan). Jurnal Al-Jami'ah vol no 22. Yogyakarta: Universitas Islam Negeri Sunan Kalijaga.

Tumijo-Slamet Riyanto. 2010. 99,99\% Sukses TOEFL. Cetakan pertama, Yogyakarta: Pustaka Widyatama. 